\title{
Study on the Relationship between Cultural Construction and Moral Cultivation in Colleges and Universities
}

\author{
Hongyan Li \\ Zhengzhou University of Industrial Technology, Zhengzhou 451100, China \\ 549106267@qq.com
}

Keywords: university culture, moral cultivation, problem, countermeasures.

\begin{abstract}
In the development and construction of university campus, the cultural construction and moral education construction of university campus are indispensable, and they occupy the core position in the development of this university. The generalized campus culture refers to material culture, spiritual culture and institutional culture. At present, the moral education of college campus construction is mainly for college students to learn Marxist basic principles to develop their ideological and moral qualities, to solve the problem of college students' thought, and for the safety of the social development of the school. The essential work of the campus itself is to impart students' cultural knowledge and cultivate students' health psychology, which are complementary and indispensable.
\end{abstract}

\section{Introduction}

Only when students grow up in a healthy environment can they truly become useful to the country and society, and the construction of colleges and universities must have a strong cultural atmosphere and a healthy mental environment. A university has not only its own cultural heritage, but also its own characteristics and innovation, the most important is its own eternal charm. The charm of the school itself must be appreciated and admired by the college students, and it must lead the college students to the good direction to a certain extent. College students must have their own heart, passion, character and noble personality. Only with these basic qualities. He can really understand the meaning of the university, the meaning of life. Cultural knowledge teaching is to let students grasp the basic survival ability, and the cultivation of moral quality is to let students establish correct outlook on life, values and world view, the real integration into society, contributing to society, to become a real member of the society.

Only in the establishment of a good relationship between cultural construction and moral cultivation, colleges and universities can cultivate high-quality talents of the society. Therefore, it is unscientific and imperfect to pay attention to the imparting of cultural knowledge and neglect the cultivation of moral quality.

Nowadays, with the development of "civilization and harmonious development", high-quality talents are becoming more and more popular. Therefore, if a person or a country wants to be invincible in this society, it must strictly grasp culture and morality, "grasp both hands and both hands should be hard". In order to maintain the healthy and stable development of a university, the relationship between the moral cultivation of the school's cultural construction is the prerequisite. 


\section{Problems in cultural construction and moral cultivation in colleges and universities.}

\subsection{The obvious construction of heavy material culture and the construction of light spiritual culture}

Campus material culture and spiritual culture is an essential part of campus culture in two parts, the campus physical culture is the foundation of the construction of campus culture and support, and spiritual culture construction is the main body structure of the campus culture construction. The purpose of the construction of campus physical culture construction is the construction of campus spiritual culture, but at present, more and more focus on material culture construction in colleges and universities, and put the construction of spiritual culture as their luxury goods, in order to pursue interests, as the purpose, will means they put a lot of money and effort in school decorative appearance, does not pay attention to the connotation and characteristics of school blindly pursuing large scale and modernization, lead to many colleges and universities are overblown, frothy, charm, thus greatly weakened the competitiveness of the university. And one more thing is the university's new campus most of them are built in the suburbs of the city, little contact with the outside world communication, can only rely on the construction of campus material culture to improve school visibility, it is very difficult to let the school is in an impregnable position.

No spiritual culture for boot, no amount of material culture construction is with the color of bamboo cup, ACTS have no true meaning, luxuriant appearance but dispensable is not possible to say the material culture construction, campus material culture and campus spiritual culture as the body and soul, the body without a soul is the walking dead, that the value of it is also really is dispensable. Therefore, the construction of spiritual culture is the essential and essential component of campus culture construction. It is the support force that exists on campus. At present, most of the construction of large seed culture deviates from this purpose. The function and meaning of campus culture can not be realized, and the construction of campus culture tends to be formalized.

\subsection{Insufficient research on the influence of the network brings to the construction of campus culture}

With the development of information technology, the use of the Internet is becoming more and more popular worldwide. Online learning and online communication become a way of life for students and gradually become popular. It has seriously affected the healthy development of college students in a certain way. In the modern era of high-tech products, online learning has taken up most of the college students' study time. On the one hand, the network broadens the horizon of contemporary college students, and students can obtain information resources more timely. However, under the impact of network culture, traditional culture is seriously challenged. Online culture has unconsciously distorted the way of life of college students. With the popularization and popularization of campus network, the campus network culture has become the most important part of college students' daily life. Network for college students to provide new way of learning, to broaden the students to acquire knowledge, to absorb nutrition, on the contrary, the network become a part of the student's poison, the network that they lose their studies, let they are too addicted to the Internet cannot extricate oneself, let they lost interest in interacting with others and to participate in collective activities, make the campus culture education lost its original meaning of education. At the same time, the campus culture of the school emphasizes the principle and the social impact, and the emergence of network media makes the stable pattern change dramatically. While it provides a free and highly Shared space, it also disseminates yellow information, black information and gray information on the Internet. However, we have not fully studied the "double-edged sword" on the Internet campus culture, and the technical preparation is insufficient and the management system is 
not perfect.

2.3 Campus cultural construction has a tendency to deviate from the basic function of campus culture, especially the social radiation effect is not outstanding, and the overall situation is low.

Found in the process of the construction of campus culture is a most of the college students for politics, the international situation is not too concerned about, such as to their positioning is not accurate, the faith, ideal is not clear, values, outlook on life are clear enough. In terms of its cultural attributes, university campus culture embodies a complete set of value system and code of conduct. Today, the vast majority of colleges and universities master and understanding of the system to a certain extent, appear to the phenomenon of education focus on, that object is in the school student of the university campus culture construction, namely to strengthen students' behavior norms and constraints. In fact, the construction of campus culture involved in the areas of the school, the results need to school life in teaching, scientific research, management, and other fields actively guide, all the teachers and students work together to achieve. In this process, it permeates all employees in the teachers and students ideology and behavior of achievement in all faculty of school physical construction, system construction, the contribution of construction, and behavior. In addition, the social value of campus culture in most colleges and universities is not reflected, and its influence on society is not exerted. Its cultural construction and cultural influence are limited to university campuses. However, as the main way of inheriting culture, colleges and universities are the main places to contact foreign cultures and have rich soil to create new culture. Because of this, the academic achievements and talents cultivated by university research should be applied in all corners of society, thus exerting a significant influence on society and social culture. Therefore, the construction of colleges and universities should adapt to the demands of social development and strive to serve the society.

\section{Countermeasures to strengthen campus culture construction.}

\subsection{Campus cultural design must adhere to the socialist core value system as the fundamental.}

Schools should use the system of socialist core values guide the requirements of the construction of campus culture, adhere to marxism as guidance, firmly set up the common ideal of socialism with Chinese characteristics, carry forward the national spirit with patriotism as the core, develop with innovation as the core spirit of The Times to firmly establish and earnestly practice "eight honors, eight disgraces" as main content of the socialism outlook for honor and dishonor. In today's cultural diversity, we should actively overcome false knowledge, establish correct understanding, and form correct world outlook, outlook on life and values. We should promote the development of advanced and healthy cultures and resolutely resist backward and decadent cultures. Secondly, the school should actively explore new ways of campus culture construction, new ways, face the world, face the future, and actively adapt to the development of modernization. School only insist on the socialist core value system leading the campus culture construction, and strive to build a harmonious campus culture, to strive to create a good campus environment is advantageous to the talent training, give full play to the role of the campus culture exerts. At the same time, the construction of campus culture should be compatible with the socialist society, only positive into the trend of social development, the campus culture can we truly achieve the value of its own, is continuously expanding. 


\subsection{It is necessary to expand the realization of campus culture design and to infiltrate campus culture construction with classroom teaching.}

In the construction of college culture, teachers and students play the role of the main body. To establish and improve the school's cultural system, teachers and students must be mobilized to participate. The construction of campus culture as an important aspect of the long-term development of the school. Enough attention must be paid.

The construction of campus culture to achieve its end stage just rely on is difficult to receive results of one branch of the school, its construction every job has relationship with schools, school construction of fundamental purpose is to serve them, and serve the society, create the environment for the students, creative talents for the society. A good campus culture can not only produce excellent university students, but also cultivate high-quality teachers. Therefore, to create a strong atmosphere of campus culture requires not only teachers' efforts, but also students' participation and high attention from school leaders.

Must have talent of education high quality university culture construction and the sustainable development of the school as a long-term planning objectives, the combination of theory and practice of education as the main means of teaching, school leaders and teachers should give full play to their own exemplary as, the real teaching, let all the teachers and students can truly experience the rich atmosphere of campus culture, play a promoting effect on construction of characteristic schools, to the cultivation of comprehensive quality talents play a role in shaping. University in imparting knowledge and technology at the same time, to make students aware of their inner spiritual strength, sets up the firm faith and beliefs, foster a kind of humanistic spirit of keeping pace with The Times, build a kind of individuality and personality perfect atmosphere, in the broad sense model of comprehensive development.

\section{Conclusion}

Campus culture, can the real from the aspects of more intuitive, cultivate the students' overall quality, it is a important way of national education policies, is important way to improve the national quality, is to explore the law of education process. The construction of campus culture and ideological and moral construction engineering is a soul, is the interaction between teachers and students cooperate with each other, is that they are fit created on the basis of the material wealth and spiritual wealth, is to make a school without solid foundation, which can ensure time real education goals. Therefore, in today's highly effective education aspect, must be very attaches great importance to the profound influence to the development of university campus culture, create a unique personality and match The Times with the campus culture, and continuous innovation, to enhance the overall level of university.

Visible, the school culture construction and ideological and moral construction is the soul of a school, a school is an important part of sustainable development for a long time, and to promote the country's prosperity, enhance the overall strength of the country.

\section{References}

[1] Wu jianping. Campus culture and talent cultivation [M]. Beijing: tsinghua university press, 2001.

[2] Yang mei. Shaping the healthy personality of college students [M]. Beijing: China youth publishing house, 1995.

[3] zhang baocheng. Analysis on the work of "three education people" in the construction of "three types of campus"

[J].Political education research, 2009 (4): 95-97.

[4] Beijing normal university. Value and culture [M]. Beijing: Beijing normal university press, 2006.

[5] To strengthen the construction of campus spiritual culture -- the cultivation of college students' ideological and moral qualities. A strategic entry point [J]. Journal of jiamusi university (social science edition), 2008 (3):47-49. 